\title{
Real-time volumetric optical coherence tomography OCT imaging with a surgical microscope
}

Gereon Hüttmann, Joachim Probst, Tino Just, Hans Pau, Stefan Oelckers*, Dierck Hillmann, Peter Koch, Eva Lankenau

From 2nd Scientific Meeting of the Head and Neck Optical Diagnostics Society

San Francisco, CA, USA. 23-24 January 2010

Optical coherence tomography is a unique technique to visualize subsurface tissue structures with a resolution below $10 \mu \mathrm{m}$ during microsurgery without tissue contact. Since it was introduced more than 15 years ago imaging speed was boosted by more than three orders of magnitude, from less than 100 to more than 300,000 A-scans per second. Instead of taking only still images of anatomical structures, the increased speed of OCT allows now to image volumes nearly in real time. This enables not only the scanning of larger tissue surfaces, but also opens new application beyond simple diagnosis. A noncontact volumetric imaging with less than $15 \mu \mathrm{m}$ resolution can guide microsurgery at the eye, in Otolaryngology (ENT) and in other medical disciplines.

Here we present an ultrahigh speed OCT system with more than $200.000 \mathrm{~A}$-scans/second integrated into a surgical microscope (MÖLLER Hi-R 1000, MöllerWedel GmbH, Wedel, Germany), which is capable of processing, rendering and displaying more than 7 volumes with 12 million pixel per second by using a PC with a high performance graphics accelerator card. Best performance was reached by distributing the calculation of the A-scans to the four cores of the PC, whereas the preprocessing and rendering was done in real-time with dedicated software on graphic processing unit (GPU). Possible applications of the system are OCT guided microsurgery in the middle ear or tumor surgery of the vocal fold.
Published: 29 October 2010

doi:10.1186/1758-3284-2-S1-08

Cite this article as: Hüttmann et al:: Real-time volumetric optical

coherence tomography OCT imaging with a surgical microscope. Head \& Neck Oncology 2010 2(Suppl 1):08.
Submit your next manuscript to BioMed Central and take full advantage of:

- Convenient online submission

- Thorough peer review

- No space constraints or color figure charges

- Immediate publication on acceptance

- Inclusion in PubMed, CAS, Scopus and Google Scholar

- Research which is freely available for redistribution
C Biomed Central 